\title{
Profile of patients with cleft palate fitted with hearing AIDS
}

\author{
Ticiana Cristina de Freitas Zambonato ${ }^{1}$, Mariza \\ Ribeiro Feniman ${ }^{2}$,Wanderléia Quinboneiro \\ Blasca ${ }^{3}$, José Roberto Pereira Lauris ${ }^{4}$, Luciana \\ Paula Maximino ${ }^{5}$
}

Keywords: cleft palate, hearing loss, hearing loss, mixed conductive-sensorineural, conductive.

\section{Summary}

\begin{abstract}
O left palates cause alterations in palate and lip structures, and it may also cause hearing loss because of recurrent otitis media. The appropriate treatment is controversial. It may include the prescription of antibiotics and insertion of a ventilation tube, or even otorhinolaryngological and audiological assistance, and hearing rehabilitation, with the use of an individual sound amplifier aid (ISAA). Aim: To characterize the profile of individuals with cleft palate and hearing loss, users of ISAA are assisted by the center of otorhinolaryngology and speech therapy of a hospital specialized in craniofacial anomalies and hearing impairment. Retrospective Study. Material and Methods: Retrospective analysis of 131 charts of patients with corrected cleft palate and hearing loss, fitted with ISAA by the center abovementioned. Results: The sample $(n=131)$ was characterized by a prevalence of females (53\%), unilateral incisive transforaminal cleft (27\%), presence of associated anomalies (51\%), history of alterations of the middle ear (56\%) and surgery intervention (56\%). Conclusion: The general profile of the individuals with cleft palate and hearing loss, fitted with ISAA, was characterized by the predominance of cleft lip and palate, positive history of middle ear alterations, surgery intervention and bilateral sensorineural hearing loss.
\end{abstract}

\footnotetext{
${ }^{1}$ MSc in Rehabilitation Sciences, Hospital of Rehabilitation and Craniofacial Anomalies at the University of São Paulo, HRAC-USP. Speech and Hearing Therapist. ${ }^{2}$ Associate Professor, Department of Speech and Hearing Therapy, Bauru Dental School, University of São Paulo, FOB-USP.

${ }^{3} \mathrm{PhD}$ in Communication Disorder Sciences, Hospital of Rehabilitation and Craniofacial Anomalies at the University of São Paulo, HRAC-USP. Professora, Department of Speech and Hearing Therapy, Bauru Dental School, University of São Paulo, FOB-USP.

${ }_{4}^{4}$ Associate Professor, Department of Dental Pediatrics, Orthodontics, and Collective Health, Bauru Dental School, University of São Paulo, FOB/USP

${ }^{5}$ PhD in Biologic Sciences - Human Genetics, UNESP at Botucatu; Professor, Speech and Hearing Therapy Department, Bauru Dental School, University of São Paulo FOB/USP.

Hospital de Reabilitação de Anomalias Craniofaciais da Universidade de São Paulo, HRAC-USP

Send correspondence to: Profa. Dra. Mariza Ribeiro Feniman - Pç. Salim Haddad Neto 13-20 apto. 1202 Vila Universitária 17012-503 Bauru SP. Paper submitted to the BJORL-SGP (Publishing Management System - Brazilian Journal of Otorhinolaryngology) on November 17, 2008; and accepted on October 5, 2009. cod. 6134
} 


\section{INTRODUCTION}

Cleft lip and palate is a malformation that involves the lip and palate structures leading to possible oral communication disorders, principally due to audiological changes and alterations in the speech-related joints, apart from introducing feeding, psychosocial, educational, dental, and cosmetic disorders. ${ }^{1}$

Cleft lip and palate patients present middle ear ventilation problems resulting from changes in the movement of the Eustachian tube caused by inadequate insertion of the palate tensor and elevator muscles, thus producing a functional obstruction on the Eustachian tube and negative pressure in the middle ear, leading to otitis media., ${ }^{2,3}$

The significant degree of association between cleft lip and palate and changes in the middle ear has been profusely described in the literature ${ }^{2,412}$ with wide agreement among authors. The most adequate therapy mode for this disorder remains yet controversial.

Various studies have supported the importance of using antibiotics and inserting the Eustachian tube during palate repair surgery to prevent the occurrence of middle ear disorders and their consequences. ${ }^{10,13-17}$ Other studies $2,7,8,9,18,19$ reported high rates of long term side effects such as perforation and retraction of the tympanic membrane, chronic otitis media, and hearing loss in the ears treated with tube ventilation insertion. Ideal treatment was then defined as otorhinolaryngological and audiological follow-up, accompanied by aural rehabilitation and use of hearing aids. The indication to insert a ventilation tube is only maintained after thoroughly discussing the matter with the patient and/or his/her guardian and explaining the possible consequences of the procedure when objective evidences of persistent effusion are present for over 3 months.

The use of hearing aids as a mode of aural rehabilitation in cleft lip and palate patients with hearing loss is a viable and relevant alternative for such individuals. It is worth mentioning that this indication requires a complex process through which the right device is chosen and validated for each patient ${ }^{20,21}$.

In such context, given the relevance of the association between cleft lip and palate and hearing loss, this study aims to characterize the profile of patients with cleft lip and palate and hearing loss using hearing aids.

\section{MATERIALS AND METHOD}

This study was approved by the Ethics Committee under permit 314/2005UEPCEP. A retrospective study was carried out on the charts of 131 patients operated for cleft lip and palate ${ }^{27,28}$ and offered hearing aids between 2001 and 2006.

This research was carried out between August of 2005 and August of 2007.
Patient charts were checked for data on patient identification (gender, date of birth, birthplace, degree of education, type of cleft lip and palate), otologic history (history of otitis, surgery), hearing (most recent audiological assessment) and hearing aid (type and model).

The classification developed by Spina et al. and modified by Silva Filho et al.was used to describe the cleft lip and palate types. This method uses the incisive foramen - the point where lip and palate are joined together - as an anatomic landmark; for clarification purposes, however, as results are presented in our study, the chosen nomenclature was cleft lip for pre-incisive foramen manifestations, cleft palate for post-incisive foramen occurrences, and cleft lip and palate for trans-incisive foramen alterations.

Results were submitted to a descriptive analysis after data collection and summarized in the form of tables to facilitate analysis and interpretation. The chi-square test was performed with a significance level of $5 \%(\mathrm{p}<0.05)$ to check for the association between the analyzed variables.

All patients in our sample are being treated and followed specifically for their craniofacial malformations and systematically followed by the Otorhinolaryngology and Speech and Hearing Therapy service at a hospital specialized in craniofacial anomalies and hearing loss.

\section{RESULTS}

Patients were aged between 2 and 72 years ( mean=23; median=20; standard deviation=14.7).

Table 1 shows the distribution of the sample according o gender and cleft type.

The presence of anomalies associated with cleft lip and palate was analyzed in all charts, and 67 (51\%) patients were found to have other anomalies associated with cleft lip and palate.

The otologic history of the studied population is shown in Tables 2 and 3, on history of otitis and surgery respectively. Among the surgical procedure performed are myringotomy to insert the ventilation tube, tympanoplasty, tympanomastoidectomy, and radical mastoidectomy.

Table 4 comprises the data on hearing as found in the most recent audiological assessments performed on the patients; patients are grouped as a function of the type of lip and palate malformation.

Use of hearing AID per type is described in Table 5.

\section{DISCUSSION}

Our study looked into the charts of 131 patients with cleft lip and palate fitted with hearing aids, with ages ranging between 2 and 72 years, most of which females. According to the literature, isolated cleft palates are more common in women, as also found in our study (Table 1), in which $62 \%$ of the female patients had cleft palates ${ }^{29}$, a statistically significant difference among genders. 
Table 1. Patient distribution according to gender and cleft type

\begin{tabular}{lccc}
\hline \multirow{2}{*}{ Cleft type } & \multicolumn{2}{c}{ Gender } & \multirow{2}{*}{ TOTAL(\%) } \\
\cline { 2 - 3 } & Male (\%) & Female (\%) & \\
\hline Lip & $2(22)$ & $7(78)$ & $9(100)$ \\
Palate & $20(38)$ & $32(62)$ & $52(100)$ \\
Lip + Palate & $40(57)$ & $30(43)$ & $70(100)$ \\
\hline TOTAL & $62(47)$ & $69(53)$ & $131(100)$ \\
\hline
\end{tabular}

$X^{2}=6,62 ; p=0,033^{*}$
Table 2. Patient distribution according to cleft type and history of otitis

\begin{tabular}{lccc}
\hline \multirow{2}{*}{ Cleft Type } & \multicolumn{2}{c}{ Otitis History } & \multirow{2}{*}{ TOTAL(\%) } \\
\cline { 2 - 3 } & Yes (\%) & No (\%) & \\
\hline Lip & $3(33)$ & $6(67)$ & $9(100)$ \\
Palate & $27(52)$ & $25(48)$ & $52(100)$ \\
Lip + Palate & $32(46)$ & $38(54)$ & $70(100)$ \\
\hline TOTAL & $62(47)$ & $69(53)$ & $131(100)$ \\
\hline
\end{tabular}

$X^{2}=1,22 ; p=0,543 n s$

Table 3. Patient distribution according to cleft type and presence of otitis and surgery

\begin{tabular}{|c|c|c|c|c|c|}
\hline \multirow{2}{*}{ Cleft type } & \multicolumn{4}{|c|}{ Otitis and surgery } & \multirow{2}{*}{ TOTAL(\%) } \\
\hline & $A(\%)$ & $\mathrm{B}(\%)$ & $\mathrm{C}(\%)$ & $\mathrm{D}(\%)$ & \\
\hline Lip & $1(11)$ & $2(22)$ & $1(11)$ & $5(56)$ & $9(100)$ \\
\hline Palate & $16(31)$ & $11(21)$ & $4(8)$ & $21(40)$ & $52(100)$ \\
\hline Lip + Palate & $24(34)$ & $19(27)$ & $8(11)$ & $19(27)$ & $70(100)$ \\
\hline TOTAL & $41(31)$ & $32(25)$ & $13(10)$ & $45(34)$ & $131(100)$ \\
\hline
\end{tabular}

$X^{2}=5,05 ; p=0,537$ ns

Legend:

A - otitis with surgery; B - otitis without surgery; C - surgery without otitis; D - neither otitis nor surgery

Table 4. Patient distribution according to cleft type, normal hearing, and hearing loss type per ear

\begin{tabular}{|c|c|c|c|c|c|c|}
\hline \multirow{2}{*}{ Cleft Type } & \multirow{2}{*}{ Right Ear } & \multicolumn{4}{|c|}{ Left Ear } & \multirow{2}{*}{ TOTAL (\%) } \\
\hline & & Normal & CD & $\mathrm{MX}$ & SN & \\
\hline \multirow{5}{*}{ Lip } & Normal & & & & & \\
\hline & CD & & & & & \\
\hline & $\mathrm{MX}$ & & & 2 & 1 & $3(33)$ \\
\hline & SN & & & & 6 & $6(67)$ \\
\hline & Total(\%) & & & $2(22)$ & 7 (78) & $9(100)$ \\
\hline \multirow{5}{*}{ Palate } & Normal & & 1 & 1 & 7 & $9(13)$ \\
\hline & CD & 3 & 7 & 2 & 1 & 13 (19) \\
\hline & $M X$ & & & 16 & 3 & $19(27)$ \\
\hline & SN & 2 & 1 & 5 & 21 & $29(41)$ \\
\hline & Total(\%) & $5(7)$ & $9(13)$ & $24(34)$ & $32(46)$ & $70(100)$ \\
\hline \multirow{5}{*}{ Lip + Palate } & Normal & & & & & \\
\hline & CD & 2 & 15 & 2 & & $19(37)$ \\
\hline & $\mathrm{MX}$ & 1 & 2 & 9 & & $12(23)$ \\
\hline & SN & 1 & 1 & 2 & 17 & $21(40)$ \\
\hline & Total(\%) & $4(3)$ & $18(14)$ & $13(10)$ & $17(13)$ & $52(100)$ \\
\hline
\end{tabular}

Legend:

CD - conductive hearing loss; MS - mixed hearing loss; SN - sensorineural hearing loss 
Table 5. Patient distribution according to hearing aid type per ear

\begin{tabular}{|c|c|c|c|c|c|c|c|c|c|}
\hline \multirow{2}{*}{$\begin{array}{c}\text { HA } \\
\text { Right Ear }\end{array}$} & \multicolumn{8}{|c|}{ HA Left Ear } & \multirow{2}{*}{ TOTAL (\%) } \\
\hline & $\mathrm{NF}$ & L-R & L-ITC & NL-R & NL-ITC & $\mathrm{NL}-\mathrm{CIC}$ & R-B & C-B & \\
\hline NA & & 10 & 1 & 5 & & 3 & 2 & 2 & $23(18)$ \\
\hline L-R & 4 & 43 & & & & & & & $47(36)$ \\
\hline NL-R & 10 & 4 & & 22 & & & & & $36(27)$ \\
\hline NL-ITC & & & & & 1 & & & & $1(1)$ \\
\hline NL-CIC & 2 & & & & & 14 & & & $16(12)$ \\
\hline R-BT & 2 & & & & & & & & $2(2)$ \\
\hline C-BT & 5 & & & & & & & 1 & $6(5)$ \\
\hline TOTAL (\%) & $23(18)$ & $57(44)$ & $1(1)$ & $27(21)$ & $1(1)$ & $17(13)$ & $2(2)$ & $3(2)$ & $131(100)$ \\
\hline
\end{tabular}

Legend:

NF - not fitted; L-R - linear retro; L-ITC - linear intracanal; NL-R - non-linear retro; NL-ITC - non-linear intracanal; NL-CIC - non-linear micro canal; $\mathrm{R}-\mathrm{B}$ - retro bone transmission; C-B - conventional bone transmission

As vastly described in the literature, $4,5,6,9,10,16,30$ this study (Table 2) also saw a large portion of cleft palate patients with history of middle ear disorders.

Most patients with cleft lip (67\%) do not have a history of otitis; in contrast, $52 \%$ of the patients with cleft palate have a history of otitis (Table 2), although no statistically significant differences were found $(p=0.543)$.

Another study reported worse air tone thresholds in patients with cleft palates when compared to cleft lip patients, indicating a greater probability of hearing loss in cleft palate patients due to middle ear disorders. ${ }^{31}$ Similar findings can be seen in Table 3, in which patients with cleft lip and palate had a larger occurrence of otitis and surgery than others, despite the lack of statistical significance $(\mathrm{p}=0.537)$.

When looking at hearing (Table 4), all types of hearing loss (conductive, mixed and sensorineural) were present in the sampled population, as well as absence of hearing involvement. It may be seen, after analyzing hearing and type of malformation, that cleft lip patients have more sensorineural hearing loss. This finding is probably related to other etiologic factors and not specifically to the cleft deformity, as only the lip is involved in this malformation. In contrast, in cleft palate alone and in cleft lip and palate cases other types of hearing loss were found, possibly justifying the presence of some important conductive component. Our findings depict structural and functional changes introduced by the occurrence of cleft palate, such as Eustachian tube disorders and middle ear infections, apart from increased rates of respiratory tract infections, hypertrophic tonsil and adenoids, and immune disorders connected to lack of breastfeeding during infancy. $2,3,4,5,6,9,10,15,32,33$

The prevalence of otitis media was reduced as a result of palate repair surgery, but it is possible that middle ear disorders linger on for a long time, until the adulthood., ${ }^{90,30,34}$ Some authors associate the persistence of otitis media after palate repair and functional disorder to patient predisposition to secondary diseases introduced by primary middle ear infections. ${ }^{35}$

Fifty six percent of the patients enrolled in our study underwent surgery to treat recurring otitis media, showing a greater tendency towards surgical treatment as also seen in the literature as a preventive approach to middle ear disorders. ${ }^{10,14-17}$

However, many discuss the possibility of offering patients a less aggressive therapy that does not introduce late complications, provided in the form of otorhinolaryngological and audiological follow-up combined with indication of hearing aids. ${ }^{1,2,5,7,8,11,18,35-42}$

Some authors state that the use of hearing aids is an effective tool in treating persistent and recurring otitis media after the ventilation tube has been removed. Additionally, they found that when the justification to treat otitis is hearing loss and the ensuing disabilities, hearing aids can be used as an effective non-invasive therapeutic measure. ${ }^{40}$

\section{CONCLUSION}

Our sample of patients with cleft lip and palate and hearing loss fitted with hearing aids may be characterized mainly as patients with cleft lip and palate with a history of middle ear disorders treated surgically in cases of recurring otitis media.

\section{REFERENCES}

1. Pegoraro-Krook MI, Souza JCRD, Magalhães LCT, Feniman MR. Intervenção fonoaudiológica na fissura palatina. In: Ferreira LP, Beli-Lopes DM, Limongi SCO, organizadoras. Tratado de Fonoaudiologia. São Paulo: Roca; 2004. p. 339-455.

2. Tunçbilek G, Özgür F, Belgin, E. Audiologic and timpanometric findings in children with cleft lip and palate. Cleft Palate Craniofac J. 2003;40(3):304-9. 
3. Shaw R, Richardson D, McMahon S. Conservative management of otitis media in cleft palate. J Craniomaxillofac Surg. 2003;31:316-20.

4. Ribeiro M, Freitas JAS. Achados otoscópicos e audiométricos em pacientes com fissura pós-forame incisivo. Acta Awho. 1991;10(2):61-7.

5. Muntz HR. An overview of middle ear disease in cleft palate children. Facial Plast Surg. 1993;9(3):177-80.

6. Carrie S, Sprigg A, Parker AJ. Skull base factors in relation to hearing impairment in cleft palate children. Cleft Palate Craniofac J. 2000;37(2): 166-71.

7. Sheahan P, Blayney AW, Sheahan JN, Earley MJ. Sequelae of otitis media with effusion among children with cleft lip and/or cleft palate. Clin Otolaryngol Allied Sci. 2002;27:494-500.

8. Sheahan P, Miller I, Sheahan JN, Earley MJ, Blayney AW. Incidence and outcome of middle ear disease in cleft lip and/or cleft palate. Int J Pediatr Otorhinolaryngol. 2003;67:785-93.

9. Sheahan P, Blayney AW. Cleft palate and otitis media with effusion: a review. Rev Laryngol Otol Rhinol. 2003;124(3):171-7.

10. Castelein S, Deggouj N, Vanwijck R, Bayet B, Reychler H. Review of the UCL management of patients with cleft lip and palate. B - ENT. 2006;2 (Suppl 4):51-6.

11. Piazentin-Penna SHA, Jorge JC. Avaliação e tratamento dos distúrbios de audição. In: Trindade IEK, Silva Filho OG, coordenadores. Fissuras Labiopalatinas: uma abordagem interdisciplinar. São Paulo: Livraria Santos; 2007. p. 165-72.

12. Feniman MR, Souza AG, Jorge JC, Lauris JRP. Achados otoscópicos e timpanométricos em lactentes com fissura labiopalatina. Rev Bras Otorrinolaringol. 2008;74(2):248-52.

13. Gordon ASD, Jean-Louis F, Morton RP. Late ear sequelae in cleft palate patients. Int J Pediatr Otorhinolaryngol. 1988;15:149-56.

14. Robinson PJ, Lodge S, Jones BM, Walker CC, Grant HR. The effect of palate repair on otitis media with effusion. Plast Reconstr Surg. 1992;89(4):640-5.

15. Portinho F, Kós AOA. Alterações otológicas nos pacientes com fissuras palatinas. In: Carreirão S, Lessa S, Zanini AS. Tratamento das fissuras labiopalatinas. $2^{2}$. ed. Rio de Janeiro: Revinter;1996. p. 25-30.

16. Timmermans K, Vander Poorten V, Desloovere C, Debruyne F. The middle ear of cleft palate patients in their early teens: a literature study and preliminary file study. B - ENT. 2006;2(Suppl.4):95-101.

17. Merrick GD, Kunjur J, Watts R, Markus AF. The effect of early insertion of grommets on the development of speech in children with cleft palates. Br J Oral Maxillofac Surg. 2007;45(7):527-33.

18. Maheshwar AA, Milling MAP, Kumar M, Clayton MI, Thomas A. Use of hearing aids in the management of children with cleft palate. Int J Pediatr Otorhinolaryngol. 2002;66:55-62.

19. Lous J, Burton MJ, Felding JU, Ovesen T, Rovers MM, Williamson I. Grommets (ventilation tubes) for hearing loss associated with otitis media with effusion in children. Cochrane Database Syst Rev. 2005;25:CD001801.

20. Campos CAH, Russo ICP, Almeida K. Indicação, seleção e adaptação de próteses auditivas: princípios gerais. In: Almeida K, Iório MCM. Próteses auditivas: fundamentos teóricos e aplicações clínicas. $2^{\underline{a}}$ ed. São Paulo: Lovise; 2003. p. 35-54.

21. Moore BCJ. Speech mapping is a valuable tool for fitting and counseling patients. Hear J. 2006;59(8):26-30.

22. Mueller HG. Probe-mic assessment of digital hearing aids? Yes, you can. Hear J. 2001;54(1):10.

23. Couto CM, Costa MJ, Almeida K. Mensurações com microfone sonda In: Almeida K e Iório MCM. Próteses auditivas: fundamentos teóricos e aplicações clínicas. 2a ed. São Paulo: Lovise;2003. p. 273-304.
24. Costa MJ. Listas de sentenças em português: apresentação e estratégias de aplicação na audiologia. Santa Maria: Pallotti; 1998.

25. Costa LP, Iório MCM. Próteses auditivas: avaliações objetivas e subjetivas em usuários de amplificação linear e não-linear. Pró-Fono. 2006;18(1):21-30

26. Boéchat EM, Russo ICP, Almeida K. Reabilitação do adulto deficiente auditivo. In: Almeida K, Iório MCM. Próteses auditivas: fundamentos teóricos e aplicações clínicas. $2^{\underline{a}}$ ed. São Paulo: Lovise; 2003. p.437-46.

27. Silva Filho OG, Ferrari Júnior FM, Rocha DL, Freitas JAS. Classificação das fissuras lábio-palatais: breve histórico, considerações clínicas e sugestão de modificação. Rev Bras Cir. 1992;82:59-65.

28. Silva Filho OG, Freitas JAS. Caracterização morfológica e origem embriológica. In: Trindade IEK, Silva Filho OG, coordenadores. Fissuras Labiopalatinas: uma abordagem interdisciplinar. São Paulo: Livraria Santos;2007. p.17-49.

29. Modolin MLA, Cerqueira EMM. Etiopatogenia. In: Altmann EBC, organizadora, Fissuras labiopalatinas. $4^{a}$.ed. Carapicuíba: Pró Fono;1997. p. $25-30$.

30. Seibert JW, Danner CJ. Eustachian tube function and the middle ear. Otolaryngol Clin North Am. 2006;39:1221-35.

31. Feniman MR, Donadon DR, Vieira JM. Audição de pacientes com fissura isolada de lábio e com fissura de palato: um estudo comparativo. J Bras Fonoaudiol. 1999; 1: 44-7.

32. Kubba H, Pearson JP, Birchall JP. The aetiology of otitis media with effusion: a review. Clin Otolaryngol Allied Sci. 2000;25:181-94.

33. Arnold WH, Nohadani N, Koch KHH. Morphology of the auditory tube and palatal muscles in a case of bilateral cleft palate. Cleft Palate Craniofac J. 2005;42(2):197-201.

34. Gudziol V, Mann WJ. Chronische tubendysfunktion und ihre folgeerkrankungen bei erwachsenen mit einseitiger lippen-kiefer-gaumenspalte. [Chronic Eustachian tube dysfunction and its sequelae in adult patients with cleft lip and palate]. HNO. 2006;54:684-8.

35. Rynnel-Dagöö B, Lindberg K, Bagger-Sjöbäck D, Larson O. Middle ear disease in cleft palate children at three years of age. Int J Pediat Otorhinolaryngol. 1992;23(3):201-9.

36. Silva AA, Maudonnet OAQ. Complicações otológicas em crianças fissuradas. Rev Bras Otorrinolaringol. 1990;56(4):151-4

37. Robson AK, Blanshard JD, Jones K, Albery EH, Smith IM, Maw AR. A conservative approach to the management of otitis media with effusion in cleft palate children. J Laryngol Otol. 1992;106:788-92.

38. Flanagan PM, Knight LC, Thomas A, Browning S, Aymat A, Clayton MI. Hearing aids and glue ear. Clin Otolaryngol Allied Sci. 1996;21(4):297300.

39. Jardine AH, Griffiths MV, Midgley E. The acceptance of hearing aids for children with otitis media with effusion. Laryngol Otol. 1999;113:314-7.

40. Ahmmed AU, Curley JWA, Newton VE, Mukherjee D. Hearing aids versus ventilation tubes in persistent otitis media with effusion: a survey of clinical practice. J Laryngol Otol. April 2001;115:274-9.

41. Rosenfeld RM, Lous J, Bluestone CD, Marchisio P, Casselbrant ML, Paradise JL et al.Recent advances in otitis media. 8. Treatment. Ann Otol Rhinol Laryngol. Suppl 2005; 194:114-39.

42. Le Saux N, Gaboury I, Baird M, Klassen TP, MacCormick J, Blanchard $\mathrm{C}$, et al. A randomized, double-blind, placebo-controlled noninferiority trial of amoxicillin for clinically diagnosed acute otitis media in children 6 months to 5 years of age. CMAJ. 2005;172(3):335-41. 